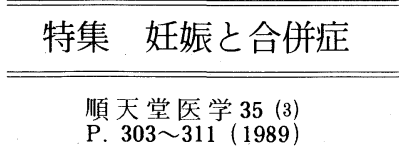

\title{
妊娠と SLE：産科の立場から**
}

Pregnancy and SLE from the obstetrical aspects

吉田幸洋*

Kō Yō YOSHIDA, M.D.

全身性エリテマトーデス (SLE) 合併妊娠は, 近年増加の傾向にある. その理由は, 管理治療 方法の進歩による長期寛解例が増え，妊娠を許可される例が多くなったてとによる。しかしな がら, 流早産や低出生体重児の頻度は依然として高く, 妊娠中の産科的管理はきわめて重要で ある. 1979年以降, 当科で管理した SLE 合併妊娠105例について検討し, 周産期管理上重要と 思われる点汇関して以下の結論を得た。（1）母体の条件のうち, 腎障害例・ループス抗凝固因 子陽性例は母児双方にハイリスクである。（2）妊娠中の血清補体価は児の予後を良く反映する。 （３）超音波断層法は, 子宮内胎児発育遅延や羊水過少の診断のみらず, 先天性胎览完全房室ブ ロックなど心拍異常の出生前診断に役立つ. また超音波パルスドプラー法による胎児胎盤循環 動態の把握は, 胎児の状態を良く反映し, 予後の判定や分婏の時期の決定に有用である（4） 妊娠中期の心拍モニタ上にあらわれる non-periodic deceleration は予後不良の徴候である.

索引用語 : 全身性エリテマトーデス, ループス抗凝固因子, 血清補体価, 子宮内胎児 発育遅延, 超音波パルスドプラー法

Key words : SLE, lupus anticoagulant, serum complement, intra-uterine growth retardation, pulsed doppler method

はじめに

全身性エリテマトーデス (Systemic lupus erythematosus ; SLE) は, 20〜30歳代の妊娠可能 な若年婦人に好発する全身性の慢性炎症性疾患で ある. 原因は不明であるが発症および増悪に免疫 学的機序か関係しており, 自己免疫性疾患の範ちゅ うの代表的な疾患である. SLE の増悪因子として は, 日光暴露・感染などとともに妊娠・流産・分 婏などがある。しかしながら，若年女性に好発し， 慢性経過をとる疾患である以上, SLE 患者にとっ

* 順天堂大学医学部産婦人科学講座講師

Department of Obstetrics and Gynecology, Juntendo University School of Medicine, Tokyo, Japan

** 第249回順天堂医学会学術集会 [May 25, 1989 開催 [July 8, 1989 原稿受領]
て結婚・妊娠・分娩という問題は避けて通るこ とのできない問題であり, 事実, 妊娠を希望す る患者は多い. 近年 SLE の病態の解明は進み, 診断・治療法の進歩から早期に診断された軽症 例や，長期寛解例が増加しており，その結果妊 娠を許可される例は増えている。しかし，SLE 妊娠における坚の予後はきわめて不良であり， 流早産や低出生体重児の頻度は依然として 高い。

SLE と妊娠との関係について論ずる場合, 通常, 2 つの方向から論じられることが多い.すなわち (1) 妊娠がSLE におよぼす影響について, およ び（2）SLE が妊娠におよぼす影響についてで ある．今回は，産科的立場で（2）のうち特に妊 娠期間中における妊娠の維持・胎児管理・婏出の 時期・予後判定などに関し, 産科学的な管理を中 心に述べてみたい。 


\section{SLE 合併娃娠の頻度}

Friedman ら ${ }^{1)}$ によれば SLE と妊娠の合併頻 度は, 妊娠1,660例について 1 例と報告されている が, 近年その頻度は増加している. 表-1は1979年 以降1988年までの10年間の，当科における SLE 合併妊娠の分婏数の変遷である. 総数は64例で, 乙の間の総分婏数 4,883 例に対する頻度は $1.31 \%$ で ある. しかし，乙乙数年その数は増加しており毎 年10例近くの分婏例があり，その頻度も $1.5 \sim 3.5$ \%となっている。一方，表- 2 は1988年 1 月から

表- 1 SLE合併妊娠・分婏の頻度

\begin{tabular}{c|c|c}
\hline 年 & SLE合併妊娠の分婏数 (頻度) & 総分婏数 \\
\hline 1979 & $4(0.81 \%)$ & 492 \\
1980 & $4(0.74)$ & 541 \\
1981 & $3(0.56)$ & 536 \\
1982 & $1(0.19)$ & 530 \\
1983 & $4(0.70)$ & 571 \\
1984 & $6(1.28)$ & 468 \\
1985 & $12(2.54)$ & 472 \\
1986 & $10(2.26)$ & 442 \\
1987 & $7(1.52)$ & 462 \\
1988 & $13(3.52)$ & 369 \\
\hline 総数 & $64(1.31 \%)$ & 4883 \\
\hline
\end{tabular}

表- 2 妊娠と合併症

(1988年 1月～12月 順天堂大 総分婏数 369)

\begin{tabular}{|c|c|c|c|}
\hline 併 & 症 & 症例数 & 頻度 $(\%)$ \\
\hline 原 & 病 & 15 & 4.1 \\
\hline 子 宮 筋 & 腫 & 9 & 2.4 \\
\hline 甲 状腺 疾 & 患 & 5 & 1.4 \\
\hline 疾 & 患 & 3 & 0.8 \\
\hline 精 神 神 経 疾 & 患 & 3 & 0.8 \\
\hline 糖尿 & 病 & 2 & 0.5 \\
\hline 呼 吸 器 疾 & 患 & 2 & 0.5 \\
\hline 卵＼cjkstart巣＼cjkstart腫 & 瘍 & 2 & 0.5 \\
\hline 性 & 病 & 1 & 0.3 \\
\hline 本 態 性 高 血 & 圧 & 1 & 0.3 \\
\hline アレルギ一性疾 & 患 & 1 & 0.3 \\
\hline 骨 筋 肉 疾 & 患 & 1 & 0.3 \\
\hline 血＼cjkstart液＼cjkstart疾 & 患 & 1 & 0.3 \\
\hline 内 分 泌 疾 & 患 & 1 & 0.3 \\
\hline 計 & & 47 & 12.8 \\
\hline
\end{tabular}

12 月までの 1 年間に当科で管理した合併症妊娠の 内容と症例数である. 当科では SLE をはじめと する膠原病合併妊娠の頻度が最も高いことがわ かる.

\section{SLE 合併娃娠の転帰}

SLE 合併妊娠では自然流産・子宮内胎児死亡 （IUFD : intra-uterine fetal death）・死産など の fetal wastage が高率で, 出生児も SFD 児 (small for date baby) であることが多(1)2)3).

1979年以降当科で取り扱った SLE 合併妊娠は, 中絶・初期流産も含めると105例であった。 その 転帰をみると（表- 3 ），何らかの理由で人工妊娠 中絶を施行した例が28例で，妊娠を継続したもの は77例である. このうち11例は初期流産で自然流 産率は $14.3 \%(11 / 77)$ である.また全妊娠に占 める人工流産を含めた流産率は $37 \%(28+11 /$ 105）で諸家の報告とほほ同様である．注目すべ きことは，妊娠中期以降の子宮内態度死亡(IUFD) または死産の例が10例あり，乙れは妊娠継続例の 13\%（10／77）ときわめて多いことである.つま り妊娠しても生児を得られるのは105例中 56 例 (53\%) にすぎない，さらに生児を得たものでも 早産の頻度が $27 \%(15 / 56)$ と高く，早産例の約 $1 / 3$ \&FD 児である.SFD 児は正期産でも $22 \%(9 / 41)$ と多く, 正期産でかつ AFD 児 (appropriate for date baby) であるのは105例 中 32 例 $(30 \%)$ ときわめて少ない，分婏様式をみ

表- 3 SLE合併妊娠の転帰

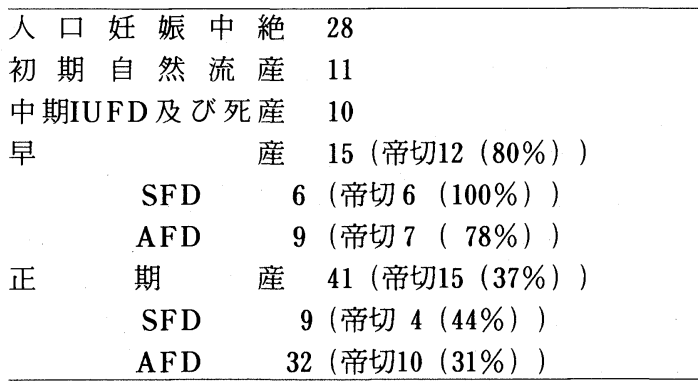


表- 4 転帰別にみたSLEの病態

\begin{tabular}{|c|c|c|c|c|c|c|c|c|c|c|}
\hline \multirow{2}{*}{\multicolumn{2}{|c|}{ 転 䚻（n ） }} & \multirow{2}{*}{$\begin{array}{l}\text { SLE罹病期間 } \\
(\text { 年 : mean } \pm \text { SD) }\end{array}$} & \multirow{2}{*}{$\begin{array}{c}\text { 腎障害例数 } \\
(\%)\end{array}$} & \multirow{2}{*}{\begin{tabular}{|c|} 
LAC陽性者数 \\
$(\%)$
\end{tabular}} & \multicolumn{6}{|c|}{ ステロイド維持量(PSLとしてmg/日) } \\
\hline & & & & & なし & $\leqq 5$ & $\sim 10$ & $\sim 15$ & $\sim 20$ & $20<$ \\
\hline \multicolumn{2}{|c|}{$\begin{array}{c}\text { 人工妊娠中絶 } \\
(28)\end{array}$} & $4.3 \pm 2.9$ & $7(25.0)$ & $3(10.7)$ & 2 & 4 & 7 & 1 & 4 & 4 \\
\hline \multirow{2}{*}{$\begin{array}{c}\text { 流 } \\
\text { 死 } \\
\text { 産 }\end{array}$} & $\begin{array}{c}\text { 初期自然流産 } \\
\text { (11) }\end{array}$ & $7.4 \pm 3.0$ & $4(36.3)$ & $2(18.1)$ & 1 & 4 & 3 & $\mathbf{0}$ & $\mathbf{0}$ & 0 \\
\hline & 中死 $_{(10)}^{\text {期IUF D }}$ & $9.0 \pm 3.2$ & $6(60.0)$ & $4(40.0)$ & 1 & 4 & 4 & $\mathbf{0}$ & 0 & 1 \\
\hline \multirow{2}{*}{$\begin{array}{l}\text { 生 } \\
\text { 産 }\end{array}$} & $\begin{array}{|lll|}\text { 早 } & & \text { 産 } \\
& (15)^{2} & \\
\end{array}$ & $9.2 \pm 3.6$ & $2(14.3)$ & $2(14.3)$ & 0 & 4 & 6 & 1 & 0 & 2 \\
\hline & $\begin{array}{|lcl|}\text { 正 } & \text { 期 } & \text { 産 } \\
& (41) & \\
\end{array}$ & $8.0 \pm 4.3$ & $9(21.4)$ & $9(4.8)$ & 8 & 13 & 16 & 2 & 0 & 0 \\
\hline
\end{tabular}

ると, SFD 児が多いことを反映して帝王切開の 頻度が高く，正期産でも $37 \%$ 早産例では $80 \%$ ， 特に早産 SFD 児では帝切率は $100 \%$ であった。

以上のように SLE 合併妊娠は児にとってきわ めて high risk であり, 妊娠中は厳重な管理が必 要である.

一方, 妊娠の転州におよぼす母体の SLE の病 態についてみると（表-4），転帰を人工妊娠中絶 群・妊娠初期自然流産群 - 妊娠中期 IUFD 群 生児を得たが早産であった群，および正期産の群 の 5 群にわけた場合, SLE の罹病期間は各群で大 きな差はないが，人工妊娠中絶群では他の群にく らべて短い傾向がある.換言すれば発症後間もな い例で，十分なコントロールがなされていない例 では妊娠継続は難しいといえる.母体にとって最 も重篤な腎障害の合併例数は中期 IUFD 群で60 $\%$ と多く, 生産群でその頻度は最も低い傾向にあ る.すなわち母体にとって重篤な腎障害は児にとっ ても不利であり, 腎障害例では厳重な管理が必要 である ${ }^{41}$. 妊娠と診断された時点でのステロイド 維持量をみると, ほとんどの例は, 当科における 妊娠許可条件 ${ }^{5)}$ であるプレドニゾロン換算で $15 \mathrm{mg}$ /日以下の範囲内であるが, 人工妊娠中絶群では $20 \mathrm{mg} /$ 日以上のものの割合が多い. これはもと もと管理不十分で, ステロイド維持量が多かった 例以外に, 妊娠に伴う SLE 病態の悪化により

\section{1. 血清補体価}

ステロイドを増量せざるを 得なかった例が含まれてい る.一方，正期産群ではす べて $15 \mathrm{mg} /$ 日以下の維持 量である.

以上の成績から, 妊娠経 過におよぼす母体の条件と しては, 長期にわたって十 分治療管理されたものであっ て, 腎症の合併のないもの, ステロイド維持量の少ない 場合に予後が良好であり， 一方，乙の条件からはずれ る場合には転帰不良の可能

性が高い。

\section{SLE 合併妊娠の転帰と関連する検査所見}

SLE は自己免疫疾患であり，血中および組織中 の免疫複合体の存在が特徵的である。その結果 SLE の活動性の指標としては，二本鎖 DNA 抗体 の増加, 血清補体価の低下, 流血中の免疫複合体 の出現などが重視されている，われわれはこのな かで, 妊娠中の血清補体価の変動に着目し, 児の 予後との関連について検討した。

一般に妊娠中の補体活性は妊娠経過とともに上 昇する ${ }^{6)}$. 図- 1 は当科で妊娠中経時的に血清補体 価を測定した SLE 合併妊娠16例を，児の予後か ら 3 群に分け各群の妊娠中の血清補体価の変動を, 当教室における妊娠各期の mean $\pm S D$ と対比し てみたものである. 図から明らかなように, 正期 産で AFD 児を得た群, すなわち予後良好群では 妊娠経過にともない血清補体価は上昇し, 妊娠後 半期では正常範囲内を推移するものがほとんどで ある. 一方, 中期 IUFD および死産群, すなわち 予後不良群では低値を持続するか, 一度上昇傾向 を示しても結局正常範囲以下に下降している. 早 産 SFD 群では一定の傾向がみられず, 上昇傾向 を示すもの, 上昇し分婏前に急に下降するもの, 

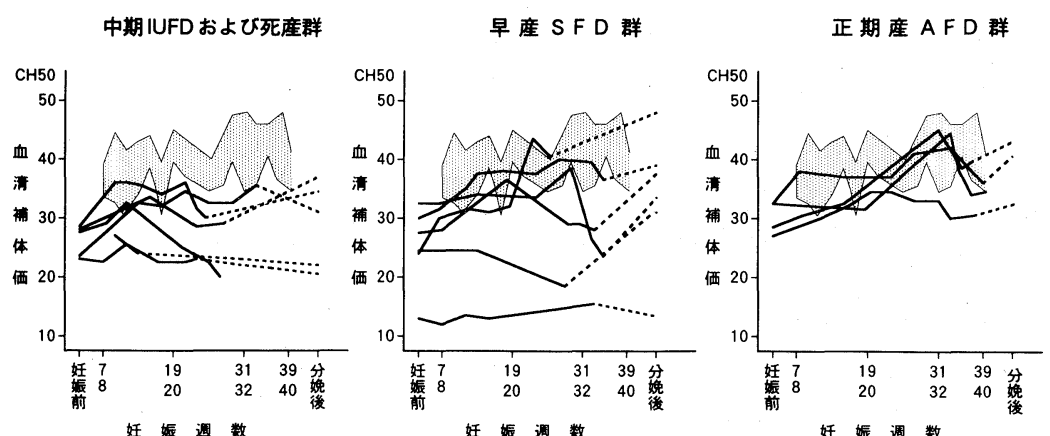

図-1 SLE合併妊娠の転㷌別にみた妊娠経過における血清補体価の変動

( 正常妊婦における血清補体価 (mean $\pm \mathrm{SD}$ )

低値を持続するものがある. このうち低値を持続 するものと, 上昇後急に下降するものは termination 直前に急性胎児仮死徵候があり, 適切な対応 により児を救命し得たものであり，結果的に早産 SFD となった例である. このような例では, 対応 が遅れれば IUFD となる可能性は高い.

安達ら SLE の活動性が認められないにもかかわらず, 血 清補体価は低值を持続するか, 上昇しても IUFD や fetal distress 発症の時期に一致して急激な 低下が認められると報告し, また, 作井ら ${ }^{81}$ は SLE 合併妊娠の胎盤を免度組織学的に検索し, 予 後不良群では補体成分の沈着が多いとし, IUFD や fetal distress の発症に対して胎盤における 免度学的な機序の関与を示唆している.

以上のでとく, 血清補体価の測定は児の予後を 推察するうえできわめて有用であり, 妊娠経過中 低值を持続する例や，上昇しても急に下降する場 合には厳重な産科管理が必要である。

\section{2.ループス抗凝固因子}

近年, ループス抗凝固因子 (Lupus Anticoagulant ; LAC) の存在が, 反復する自然流産や IUFD の原因として注目されている ${ }^{9)}{ }^{10)}$. LAC の本態 に関しては現在不明の点が多く, 抗リン脂質抗体, 特に抗カルジオリピン抗体との異同が論じられて いるが, 免疫グログリン $(\operatorname{IgG} ・ \operatorname{Ig} M$, あるいは両 方）であること，血液凝固に必要なリン脂質と反 応し, 止血検查に打いては抗凝固作用を呈
するととが明らかとなっている。しかし，生体内 では LAC は血栓形成と強い相関があり，その機 序としては LAC が血管内皮細胞のリン脂質と反 応し，その結果プロスタサイクリンの産生を低下 させ, 血小板の凝集を促進させるためと推測され ている.すなわち, 妊娠中においては, この LAC が子宮筋層を通り胎盤に行く血管に血栓をつくり， 胎盤梗塞を引きおこすと考えられている.

当科における SLE 合併妊娠例のうち, カオリ ン凝固時間でスクリーニングした LAC 陽性者は 6 例である（表- 5 ）． その妊娠歴をみると, 最高 8 回の自然流産歴を有するもの（症例 2 ）や, 2 回の自然流産のほか, 妊娠中期から後期に IUFD を経験しているもの（症例 1 ）など, 流産やIUFD の頻度がきわめて高率である.さらに，妊娠中， あるいは分婏後に母体の多蔵器血栓症というきわ めて重篤な合併症をおこした例もあり ${ }^{111}$ ，LAC 陽性例は母児双方にとってきわめてハイリスクで あるといえる。

現在 LAC 陽性例に対し, われわれはステロイ ドとアスピリンの併用療法 ${ }^{12)}$ を行うとともに，血 漿交換療法や血漿吸着療法 ${ }^{13)}$ を試みており, 徐々 に成果を挙げつつある。

\section{SLE 合併妊娠の産科管理}

近年, 超音波断層法をはじめとする $\mathrm{ME}$ 機器 の進歩はめざましく, 妊娠中および周産期管理は 
表-5 Lupus anticoagulant 陽性者とその妊娠分婏歴

\begin{tabular}{|c|c|c|c|c|c|c|}
\hline \multirow[b]{2}{*}{ No. } & \multirow[b]{2}{*}{$\begin{array}{l}\text { 婚娠 } \\
\text { 数 }\end{array}$} & \multicolumn{5}{|c|}{ 帰 } \\
\hline & & 1978年以前 & 1979年以降 & $\begin{array}{c}\text { 妊娠時 } \\
\text { LAC陽性 } \\
\text { の有無 }\end{array}$ & 備 & 考 \\
\hline 1 & 5 & 自然流産 2 回 & $\begin{array}{l}29 \text { 歳 } 28 \mathrm{w} \text { 子宮内胎児死亡 } \\
30 \text { 歳 } 38 \mathrm{w} \text { 帝王切開 }-2,685 g \text { の生児 } \\
37 \text { 歳 } 24 \mathrm{w} \text { 子宮内胎児死亡 }\end{array}$ & $\begin{array}{rr}\text { 不 } & \text { 明 } \\
\text { 不 } & \text { 明 } \\
\text { LAC } & (+) \\
\end{array}$ & & \\
\hline 2 & 8 & 自然流産 6 回 & $\begin{array}{l}\text { 32歳 } 7 \mathrm{w} \text { 自然流産 } \\
\text { 37歳 } 8 \mathrm{w} \text { 自然流産 }\end{array}$ & 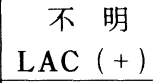 & & \\
\hline 3 & 1 & なし & 21歳人工絶 & 不 明 & & \\
\hline 4 & 1 & なし & 26 歳 $22 \mathrm{w}$ 子宮内胎児死亡 & $\operatorname{LAC}(+)$ & & \\
\hline 5 & 3 & 自然流産 2 回 & 31 歳 $30 \mathrm{w}$ 帝王切開 $-1,090 \mathrm{~g}$ の生児 & $\operatorname{LAC}(+)$ & $\begin{array}{l}\text { PSL } 20 m g \\
\text { Aspirin } 100 m g \text { 併用 } \\
\text { 多臟器血栓症を併発 }\end{array}$ & \\
\hline 6 & 3 & 自然流産 2 回 & 32歳 $17 \mathrm{w}$ 子宮内胎児死亡 & $\operatorname{LAC}(+)$ & $\begin{array}{l}\text { 血槳交換療法 } \\
\text { 多臟器血栓症を併発 }\end{array}$ & \\
\hline
\end{tabular}

画期的な進歩を遂げた。

\section{1. 超音波断層法}

超音波断層法によれば，妊娠中の胎览の形態の 観察のみならず機能的な評価も可能である。ここ では周産期管理の一般的な事項は割愛し, SLE 合 併妊娠の胎児管理において重要と思われる点につ いて述べる.

1 ）胎児発育の評価

子宮内胎児発育遅延（IUGR； intra-uterine growth retardation) となる例の多い SLE 合併 妊娠では, 妊娠中の胎児発育の評価は重要である. 胎児発育の評価は体重でなされることが多く, 児 体重推定は周産期胎児管理の基本といえる. 超音 波により児体重を推定する方法としては, 胎児各 部のうち览頭大横径 $(\mathrm{BPD}) \cdot$ 上腹部周囲長 $(\mathrm{AC}) \cdot$ 脊椎長・大腿骨長 $(\mathrm{FL})$ などを計測し,てれらを 組み合わせ体重推定式にあてはめて行う. 実用的 で簡便，非常に正確な方法はいまだないが，われ われはBPD とACを組み合わせる Shepard ら ${ }^{14)}$ の方法を用いている. ての方法による推定 体重と実際の体重との誤差は, われわれの経験 では10\%以下と考えている. 推定体重式での問 題点としては, IUGR のタイプのうち栄養障害 型と考えられる asymmetrical IUGR の場合に
誤差を生じやすいということや，低体重児ほど誤 差の割合が大きくなることがあげられるが，超音 波断層法により胎児発育がほぼ正確に把握可能と なったととは, 胎児管理上きわめて有意義である.

2 ) 羊水量の測定

羊水量は, 羊水の産生と消退が一定の平衡を保 つととにより維持されている. 妊娠中期以降の羊 水の主要な産生系は胎児尿であるため, 羊水量は 胎児の循環系之腎尿路系の機能と密接な関係があ る. 羊水量が減少するととを羊水過少というが, SLE 合併妊娠では, IUGR とともに羊水過少と なることが多い. 羊水過少では胎児の子宮内での 胸郭運動が制限されるため肺の機能的成熟が遅れ る. また, 羊水量の減少により, 胎盤・臍帯が容 易に圧迫されるため高頻度に胎児仮死を発症する.

超音波断層法によれば, 非侵襲的に羊水量の測 定が可能である。一般的には Manning ら ${ }^{15)}$ の羊 水ポケット法が用いられる。乙れは超音波画像上, 胎児と子宮壁との間に生ずるエコーフリースペー スをポケットと名付け, 乙れが径 $1 \mathrm{~cm}$ 以下のとき 亿羊水過少と診断するという方法である. 簡易法 であるが精度は高く，臨床的に十分実用的な方法 といえる。

SLE 合併妊娠のようなハイリスク妊娠の管理 


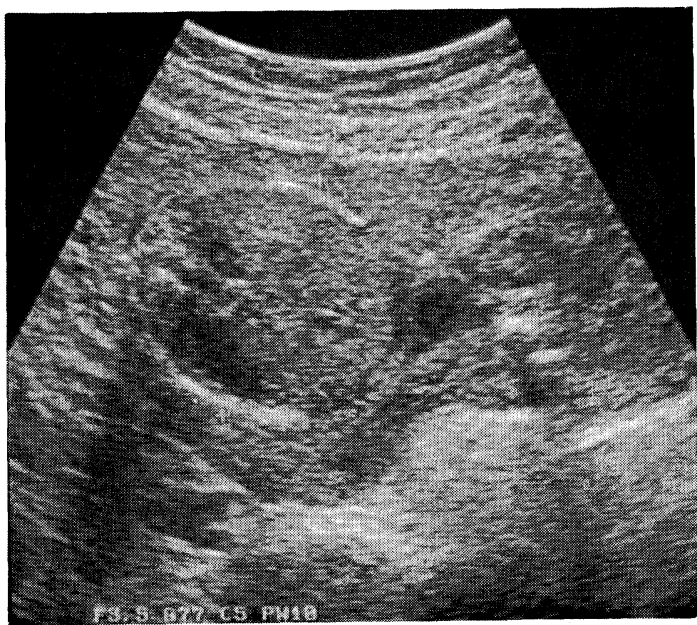

図- 2 SLE合併妊娠の羊水過少例（妊娠25週）

羊水ポケットは $1 \mathrm{~cm}$ 以下であり, 羊水はほとんど 認められない.

\section{上, 羊水量の測定は重要な意味を持つ（図-2）.}

3 ) 胎児循環動態の把握

SLE 合併妊娠における IUGR の発症の原因の 1つとして, 子宮胎盤循環不全があげられる. 近 年, 超音波ドプラー法により子宮胎盤循環や胎児 胎盤循環動態の観察が可能となり, IUGR と胎盤 循環不全との関係が検討されている ${ }^{16)}{ }^{17)}$.
Meizner ら ${ }^{18)}$ は SLE 合併妊娠に対し, パルス ドプラー法で連続的に子宮動脈と臍帯動脈の血流 波形解析を行い, IUGR の発症以前加ら子宮動脈 と, それにやや遅れて臍帯動脈の拡張期血流速度 に低下がみられることを報告し, IUGR の発症の 予知に血流計測が役立つと述べている.

図-3は当科で管理した SLE 合併妊娠例におけ る臍帯動脈の, 血流波形より求めた RI（Resistence Index）の妊娠経過に伴う変化をみたもので ある. RI とは（収縮期最高血流速度一拡張期血流 速度） $\div$ 拡張期血流速度であり, 胎盤の循環抵抗 をあらわす示標である. 正常例では RI は妊娠経 過にともない漸減する. RI が高值を示した 2 例 は, いずれも予後不良例であり，1例は経過観察 中に子宮内胎児死亡となり, 他の 1 例は妊娠後半 期であったため RI が高值（RI=1）となった後 に termination を行い, 生児を得ることができ た例である。

Giles ら $^{19)}$ は臍帯動脈の血流波形解析結果と胎 盤の病理組織検査結果を対比し, $\mathrm{A} / \mathrm{B}$ 比 (A ; 収縮期最高血流速度 $\mathrm{B}$; 拡張末期血流速度）が 高值を示した例では, 終末䋐毛内の小動脈の減少・ 閉塞がみられることを示した. SLE 合併妊娠例の うち, 特に LAC 陽性例や低補体例では, 血栓に よる小動脈の閉塞や梗塞が予想 され，予後不良例における胎盤 循環抵抗指標の上昇との関連性 は非常に興味深い。

臍帯動脈血流波形解析は IUGR の発症予知のみならず, high risk 例の termination 時期の 決定にも役立つ指標である.

4 ）超音波 Mモード法による 胎児心蔵の観察

母体の抗 SS-A 抗体保有と新 生児ループスエリテマトーデス， なかでも先天性胎児完全房室ブ ロック（CCAVB）の発症の間 には密接な関係があるとされて いる20). 実際には抗 SS-A 抗体

図- 3 SLE合併妊婦 9 例の臍帯動脈血流波形より求めたRIの変動 


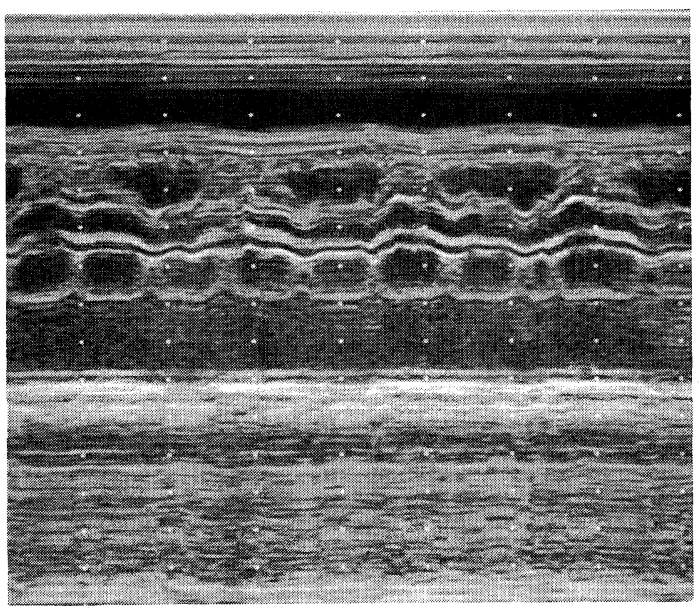

図-4 抗SS-A抗体陽性例（16倍）での先天性胎児完全 房室ブロックの 1 例

超音波Mモード法により胎児心臓の房室弁の動きをみると， 心房収縮にともなう棘波状の動きと, 心室収縮に伴う大きな動 きが完全に独立し，解離している（妊娠27週）。

保有母体における児の CCAVB の発症頻度はそ れほど高率ではないが, CCAVB の児の母親の抗 SS-A 抗体保有率は高(21). CCAVB は妊娠中か ら存在し, 超音波 Mモード法によれば妊娠中期
以降で胎内診断可能である（図-4）。すなわち, 抗 SS-A 抗体陽性例では胎児心臟形態の観察, M モード法による心室壁, 心室中隔・房室弁の動き の観察は必要不可欠である.

2 . 胎児心拍数モニタリング

妊娠中の胎児心拍数モニタリングは, 無侵襲に 胎児の well-being を評価できる方法であり，ノ ンストレステスト（NST）と呼ばれ広く普及して いる.さらに NST では, 胎児心拍数図上の異常 パターンから潜在性胎児仮死や急性胎児仮死を早 期に発見することも可能であり, 超音波断層法検 查と同様, 周産期管理上必要不可欠である.

一般に NST は, 胎動とてれにともなう胎児心 拍数の一過性頻脈 (acceleration) との関係を評 価するものであり, 両者の関係が緊密となる妊娠 32週以降に実施されることが多かった。しかし， 最近 Druzin ら ${ }^{22)}$ は SLE 合併妊娠例15例に, 妊 娠中期（妊娠19〜26週）で胎児心拍モニタリング を行い，抗凝固因子を有する例を含む 5 例に nonperiodic deceleration が出現, 乙れらはいずれも 予後不良であったと述べ, SLE 合併妊娠では妊娠 中期での胎児心拍モニタリングの重要性を強調す ると同時に, non-periodic deceleration が出 現した場合は termination を考慮すべ きと述べている．われ われも予後不良の SLE 合併例に妊娠 週で, non-periodic deceleration の出現 をみた例を経験した (図-5).

図- 5 SLE合併妊娠の子宮内胎巟死亡例に認められた non-periodic deceleration 


\section{おわりに}

SLE 合併妊娠について主として胎児管理を中 心に述べた. SLE 合併妊娠例にかかわる問題とし ては，他にも胎盤・羊水といった胎児付属物に関 するもの, 分婏後の母体の変化や新生児に関する ものなど多くの問題がある. また妊娠中の治療, 特にステロイド剤については, 胎児への移行の問 題, 授乳の問題など検討すべき点は多い.

近年, 免疫学の進歩により SLE の病態は徐々 に解明されてきている.また，産科学的な管理法 の進歩はめざましく, 未熟児の管理法の進歩とも 相俟って SLE 合併妊娠の胎児予後にも改善のき ざしがみえてきている.しかし一方, 免疫学的に 考えると複雑かつ難解な弤娠という現象が, 免疫 異常を基礎とする SLE と合併した結果, これら のからみあいについて, なお不明の点は少なくな い. 今後は, 同じく免疫学的基礎をもつ妊娠と SLE という両者の接点から,さらに詳細な病態の 解明が望まれる.

稿を終えるにあたり，で指導・で校閲を賜りました高 田道夫教授に深謝します。

\section{文献}

1) Friedman, E. A. and Rutherford, J. W.: Pregnancy and lupus erythematosus. Obstet. Gynecol., $8: 601 \sim 610,1956$

2 ) Donaldson, L. B. and DeAlvarez, R. R.: Further observation on lupus erythematosus associated with pregnancy. Am. J. Obstet. Gynecol., 83 : 1461 1473, 1962

3 ) Fraga, A., Mintz, G., Orozco, J., et al.: Sterility fertility rates, fetal wastage and morbidity in systemic lupus eryhematosus in pregnancy. J. Rheumatol, $1: 293 \sim 298,1974$

4 ) 金子隆弘, 橋本武次, 古谷 博, 他 : 高度の腎機能 障害を伴った SLE 合併妊娠の 1 例. 日産婦東京会誌, 36 : $144 \sim 147,1987$

5 ) 橋本博史：膠原病妊婦に対するケア. 臨床免疫, 20 : $657 \sim 665,1988$
6 ) 野本晴夫, 上原直樹, 阿部重人, 他 : 妊娠を合併し た全身性エリテマトーデス患者の臨床免度学的検討.

臨床免疫, $12: 808 \sim 814,1980$

7 ) 安達英夫, 新井正夫, 柏崎禎夫 : 全身性エリテマ トーデスの妊娠における血清補体価の変動に関する研 究. 臨床免疫, $11: 223 \sim 228,1979$

8 ) 作井久孝, 吉村泰典, 多田 伸, 他：SLE 合併妊 娠における母児血液の血清学的検索ならびに胎般の免 疫組織学的研究. 日産婦誌, $41: 249 \sim 256,1989$

9 ) 大㚘芳朗, 谷沢 修 : Lupus anticoagulant と 習慣性流産. 産と婦, $54: 1789 \sim 1793,1987$

10）本野千穂, 谷口 修, 広瀬俊一：ループスアンチ コアグラント. Medical Practice, 4 : 552〜 555, 1987

11）淡路正則, 庄野マリ，吉田幸洋, 他：Lupus anticoagulant 陽性の SLE 合併妊娠例. 日産婦東京会 誌, $37: 305 \sim 307,1988$

12) Lubbe, W. F., Palmer, S. J., Butler, W. S., et al.: Fetal survival after prednisone suppression of maternal lups-anticogulant. Lancet, $1: 1361 \sim 1363,1983$

13）津田裕士, 東名正幸, 藤田 新, 他 : プラズマフェ レーシスの効果と今後の課題. 病態生理, 5 ： 435〜 439, 1986

14) Shepard, M. J., Richards, V. A., Berkowitz, R. L., et al.: An evaluation of two equations for predicting fetal weight by ultrasound. Am. J. Obstet. Gynecol., 142 : 47 54, 1982

15) Manning, F. A., Platt, L. D., Sipos, L.: Antepartum fetal evaluation : development of a fetal biophysical profile. Am. J. Obstet. Gynecol., 136 : 787 795, 1980

16) Campbell, S., Diaz-Recasens, J., Griffin, D. R., et al.: New doppler technique for assessing uteroplacental blood flow. Lancet, 1 : 675 677, 1983

17) Wladimiroff, J. W., Wijingaard, J. A. G. W., Degani, S., et al .: Cerebral and umbilical arterial blood flow velocity waveforms in normal and growth-retarded pregnancies. Obstet. Gynecol., 69 : 705 709, 1987

18) Meizner, I., Mazor, M., Leiberman, J. R., et al.: Antenatal assesment of utero-feto-pla- 
cental blood velocity waveforms in a pregnant patient with severe systemic lupus erythematosus. Isr. J. Med. Sci., $23: 290 \sim 291,1987$

19) Giles, W. B., Trudinger, B. J., Baird, P. J. : Fetal umbilical artery flow velocity waveforms and placental resistance : pathological correlation. Br. J. Obstet. Gynecol., 92 : 31 38, 1985

20) Esscher, E., Scott, J. S.: Congenital heart block and maternal systemic lupus eryhematosus. Br. Med. J., 1 : 1235 1238, 1979
21) Scott, J. S., Maddison, P. J., Taylor, P. V., et al.: Connective-tissue disease, antibodies to ribonucleoprotein, and congenital heart block. N. Eng. J. Med., 309 : 209 212, 1983

22) Druzin, M. L., Lockshin, M., Edersheim, T. G., et al.: Second-trimester fetal monitoring and preterm delivery in pregnancies with systemic lupus erythematosus and/or circulating anticoagulant. Am. J. Obstet. Gynecol., 157 : $1503 \sim 1510,1987$

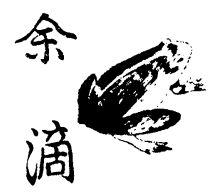

ファイバースコープが開発されて, 内腔蔵器, とく に消化管のほとんどの部位を直接に観察したり，写真 撮影したり, バイオプシーして検査するてとが可能と なった．かつての直達鏡検査を経験された方々には， 隔世の感があるに違いない，直腸鏡も真直ぐな金属製 のものであったときには，それで観察できる範囲はS 状結腸の下端までに限られていた。 それでも直腸鏡と 呼ぶよりは Sigmoidoscope, 即ちS状結腸鏡という 名称がより一般的であった。 また同じ物を呼ぶのに Romanoscope という名称もあった. Colon sigmoideum はギリシャ語風につづられていて，乙の 部分の形がシグマよりもエスに似ているのであれば, なるほど Colon S-romanum とすべきなのかも知 れないし，従って，そこまで観察する内視鏡は Romanoscope と呼ばれるべきなのかと，そんな風 に永い間納得していた。

ところが, HYRTL の Onomatologia anato- mica の Sigmoideum の項によると, まずS状と いう形容詞を使用したローマ人にとって, シグマとは Cで書かれる字母だったのだそうである．そのような 用法がギリシャ人にもあって，新月を“美しく新しい 天空のシグマ”といった例などを HYRTL は挙げ ている.つまり, sigmoideus = semilunaris であっ たと. そして, S-romanum という名称は, はるか に下って WINSLOW (1669-1760) が導入し, 彼は Curvatura sigmoidea recti \&. romanum 呼んだと HYRTL は記載している. ギリシャ字母の シグマとローマ字母のC, それにSの混同を持越した なかに，真直ぐな腸と屈曲した腸の名称の混乱が加わっ たわけである. 解剖学の学名のなかには, 形の類似から 名づけられているものか沙なくないが, 時代力䔟りかわっ ていくと，もとの意味が失われたり，物の形が変わって いったりして, 名前力堎って解秎されてしまうことがあ るという一例であろう。 (放射線科 久留 裕) 